\title{
EFFECT OF CHRONIC IMMOBILIZATION STRESS ON KIDNEY FUNCTION IN RENAL ISCHEMIA/REPERFUSION RAT MODEL
}

\author{
By \\ Noha S. Sobhy*, Mona A. Ahmed*, Noha N. Lasheen*، \\ Mohamed H. ElSayed* and Walaa Baher** \\ Departments of Physiology* and Histology and Cell Biology**, Faculty of Medicine, \\ Ain Shams University \\ Corresponding Author Email:Nohasayed140@gmail.com
}

\begin{abstract}
Background: Renal ischemia/reperfusion (I/R) injury, a common and important cause of acute kidney injury (AKI), is considered a major socioeconomic health problem. Stress, a state of disrupted normal homeostasis is known to trigger the progression of many illnesses.

Objectives: This study was designed to determine changes in renal function and structure induced by renal $\mathrm{I} / \mathrm{R}$ in rats subjected to chronic immobilization stress and to elucidate the possible underlying mechanism(s).

Materials and Methods: Forty seven adult male albino rats were allocated into 3 groups: Group I: ShamOperated Control, Group II: Renal I/R in which rats were subjected to 45 minutes ischemia followed by 24 hours of reperfusion, and Group III: Stressed Renal I/R in which rats were separately subjected to immobilization stress, 2 hours/day for 4 weeks, and then exposed to renal I/R procedure. All rats were subjected to determination of body weight (BW) and kidney weight (KW), plasma levels of creatinine, urea and tumor necrosis factor- $\alpha$ (TNF- $\alpha$ ), as well as renal tissue levels of malondialdehyde (MDA), nitrite and catalase activity. Kidney tissues were also examined histopathologically.

Results: Stressed renal I/R group showed significant decrease in final BW, BW \% change, KW and $\mathrm{KW} / \mathrm{BW}$, and significant increase in plasma levels of creatinine, urea, TNF- $\alpha$, renal tissue MDA, and nitrite levels as compared to both renal I/R and sham-operated groups. Renal catalase significantly increased as compared to renal I/R group, but significantly decreased compared to sham-operated group.

Stress provoked significant augmentation in renal histomorphological damage scores compared to renal $\mathrm{I} / \mathrm{R}$ and sham groups, evidenced in the form of glomerular capsular thickening and tuft retraction, tubular cells necrosis with loss of brush borders and cast formation, interstitial cell necrosis and hemorrhage, and endothelial cell disruption.
\end{abstract}

Conclusion: Chronic immobilization stress aggravated renal dysfunction and morphological disturbance induced by renal I/R injury. Accentuation of oxidative stress, inflammation and nitric oxide may contribute to such effect.

Key words: Kidney, ischemia/reperfusion injury, chronic immobilization stress. 


\section{INTRODUCTION}

Renal ischemia/reperfusion (I/R) injury, a common and one of the most important causes of acute kidney injury (AKI), was defined as re-striction of blood supply to kidney followed by restoration of blood flow and reoxygenation (Malek and Nematbakhsh, 2015). $\mathrm{AKI}$ of ischemic nature is the most common form of intrinsic renal disease in adults, and was found to be associated with adverse clinical outcomes that may have significant impact on an individual's morbidity and life expectancy (Gardner et al., 2016).

The main pathophysiologic effect in renal $\mathrm{I} / \mathrm{R}$ injury is depletion of intracellular energy reserve that leads to a series of complex biochemical, pathological and physiological injuries (Ghasemi et al., 2015). The ischemiainduced lowering of oxygen supply might switch the tissue metabolism from aerobic to anaerobic state, thereby reducing the intracellular ATP levels (Kosieradzki and Rowinski, 2008). (Bonventre \& Yang, 2011) and (Munshi et al., 2011) mentioned that the reduced metabolic supply, in relation to the tissue demand during the ischemic period, induces severe hypoxia that causes microvascular dysfunction. Also, the subsequent reperfusion was found to induce more organ damage through activating several mechanisms such as innate and adaptive immune responses and apoptosis, as well (Chen and $N u$ ?ez, 2010), in addition to the excessive reactive oxygen species (ROS) production during the period of reperfusion (Granger and Kvietys, 2015).

Stress is an unavoidable phenomenon in the world that can trigger physical, mental and chemical responses in the body (Bitgul et al., 2013). At the cellular and molecular levels, stress responses can lead to oxidative damage via impairment of antioxidant defenses, thus, stress has been implicated in the pathogenesis of many diseases (Zhu et al., 2014). Studies have shown that restraint stress affected cellular integrity in many tissues, including heart, stomach, brain and especially the liver (Buynitsky \& Mostofsky, 2009 and Samarghandian et al., 2016). Also, chronic restraint stress was found to serve as an additional stress that may play additive roles in aggravating physical and psychiatric diseases (Li et al., 2017). To our knowledge, the effect of stress exposure prior to renal $I / R$ is lacking.

The present study was carried out to investigate renal functional and structural changes induced by renal $\mathrm{I} / \mathrm{R}$ in rats subjected to chronic immobilization stress, in a trial to elucidate the possible underlying mechanism(s).

\section{PATIENTS AND METHODS}

Animals:

The study was carried out on 47 adult male Wistar albino rats, initially weighing 260-330 g. When first arrived at The Faculty of Medicine, Ain Shams University Research Institute (MASRI) animal house, rats were acclimatized for 7 days prior to experiments in plastic cages measured $35 \times 25 \times 20 \mathrm{~cm}$ with every 3 rats in a cage, under standard conditions of boarding at room temperature (22-25oC), with normal light/dark cycle, and free access to food and water throughout the whole period of the study. Regular meals were introduced daily at 8 a.m in the form of milk, balady bread and green vegetables. Animal experiments were conducted in accordance to the Guide for Care and Use of Laboratory Animals, and the study protocol was approved by the Research Ethical Committee of Faculty of Medicine, Ain Shams University.

Experimental Protocol:

Rats were randomly divided into three groups:

Group I: Sham-Operated Control $(n=17)$ : Rats were left undisturbed in their home cages throughout the 4 weeks period. At the end of the 4 weeks, rats were subjected to the same 
surgical procedures as renal I/R group without bilateral renal clamping.

Group II: Renal I/R (n=15): Rats underwent renal ischemic reperfusion insult (45 minutes ischemia followed by 24 hours of reperfusion) according to (Gholampour et al., 2017) with modifications.

Group III: Stressed Renal I/R (n=15): Rats were separately subjected to immobilization stress in tight animal restraining cages (Curtin Mathesson Scientific, regular size) in the prone position at room temperature, 2 hours daily (from 10 a.m to 12 a.m), 6 days/week for 4 weeks (Mohamed et al., 2007). At the end of the 4 weeks, rats were subjected to renal I/R procedure as group II.

Induction of renal I/R: Renal $I / R$ was performed according to the method described by (Gholampour et al., 2017) with modifications. The overnight fasted rats were weighed and anesthetized by intraperitoneal (i.p.) injection of xylazine (EPICO) in a dose of $10 \mathrm{mg} / \mathrm{kg}$, and ketamine hydrochloride (EPICO) in a dose of $100 \mathrm{mg} / \mathrm{kg}$ (Yeboah et al., 2008). When the stage of surgical anesthesia had been reached, judged by loss of withdrawal reflexes, the animal was placed on its back and fixed on the dissecting table. Under complete aseptic conditions, a midline abdominal incision was done; the intestines were moved apart in order to expose both kidneys which were located in the retroperitoneal region. Both left and right renal pedicles were bilaterally clamped with non-traumatic vascular clamps for 45 minutes.

After clamping, color of the kidneys was observed for turning pale denoting establishment of renal ischemia. Then, the intestine was replaced into the abdominal cavity and covered with moistened cotton to minimize evaporation and cooling. Subsequent to the ischemic period of 45 minutes, the clamps were gently removed, and the kidneys were observed for 5 minutes until their colors turned brown confirming restoration of blood flow and reperfusion. Then, the abdominal wall including the muscular layer and the skin was closed using silk (2-0) suture. The animals were then allowed to recover with free access to food and water. The reperfusion was allowed for 24 hours.

Experimental Procedures: On the day of scarification, overnight fasting rats were anesthetized by i.p. injection of pentobarbital sodium (El-Gomhoreya Co., Egypt $40 \mathrm{mg} / \mathrm{kg}$ ). Blood samples were collected from abdominal aorta into 2 plastic heparinized tubes: One tube centrifuged at $3000 \mathrm{rpm}$ for 15 minutes and the separated plasma was stored at $-80^{\circ} \mathrm{C}$ for later determination of plasma creatinine by colorimetric kinetic method according to (Bartles et al., 1972), using kits supplied by Bio-diagnostic, Egypt, and urea by the enzymatic colorimetric Urease-Berthelot method according to (Fawcett and Soctt, 1960), using kits supplied by Bio-diagnostic, Egypt.

The second tube was centrifuged at 1000 rpm for 15 minutes and the separated plasma was stored at $-80^{\circ} \mathrm{C}$ for later determination of tumor necrosis factor- $\alpha$ (TNF- $\bullet$ ) by an enzyme immunoassay (ELISA) technique (Infinite F50, Germany), using kits supplied by Wuhan EIAab $^{\circledR}$ science Co., China.

Both kidneys were carefully dissected and weighed in 5-digit Meter balance (Sartorius AG, BL-210S, and USA). The left kidney was used for subsequent histological examination.

The right kidney was washed in ice cold normal saline, and stored in parafilm at -80 ?C for subsequent determination of oxidative stress marker malondialdehyde (MDA) according to (Satoh, 1978) and (Ohkawa et al., 1979), catalase activity according to (Aebi, 1984), and nitrite level according to (Montgomery and Dymock, 1961). MDA, catalase and nitrite were measured by colorimetric methods using kits supplied by Bio-diagnostic, Egypt. 


\section{Histopathological examination:}

The left kidney was fixed in $10 \%$ buffered formalin solution immediately after removal (for at least 1 week) and were subjected to dehydration in ascending grades of alcohol, cleared in xylol, impregnated in pure soft paraffin and embedded in hard paraffin. Longitudinal sections of 7 micron thickness were cut by microtome, stained by
Hematoxylin and Eosin (H\&E), and examined using light microscope (Cook, 1974).

The kidney histopathological changes were quantified using the endothelial, glomerular, tubular and interstitial (EGTI) scoring system devised specifically for animal research on kidney tissue in the context of injury (Khalid et al., 2016).

\section{Table (1): The EGTI Histology Scoring System (Khalid et al., 2016)}

\begin{tabular}{|c|c|c|}
\hline Tissue type & Damage & Score \\
\hline \multirow{5}{*}{ Tubular } & No damage & 0 \\
\hline & $\begin{array}{l}\text { Loss of Brush Border (BB) in less than } 25 \% \text { of tubular cells. } \\
\text { Integrity of basal membrane }\end{array}$ & 1 \\
\hline & $\begin{array}{l}\text { Loss of BB in more than } 25 \% \text { of tubular cells, Thickened basal } \\
\text { membrane }\end{array}$ & 2 \\
\hline & $\begin{array}{l}\text { (Plus) Inflammation, Cast formation, Necrosis up to } 60 \% \text { of } \\
\text { tubular cells }\end{array}$ & 3 \\
\hline & (Plus) Necrosis in more than $60 \%$ of tubular cells & 4 \\
\hline \multirow{4}{*}{ Endothelial } & No damage & 0 \\
\hline & Endothelial swelling & 1 \\
\hline & Endothelial disruption & 2 \\
\hline & Endothelial loss & 3 \\
\hline \multirow{4}{*}{ Glomerular } & No damage & 0 \\
\hline & Thickening of Bowman's capsule & 1 \\
\hline & Retraction of glomerular tuft & 2 \\
\hline & Glomerular fibrosis & 3 \\
\hline \multirow{5}{*}{$\begin{array}{l}\text { Tubulo/ } \\
\text { Interstitial }\end{array}$} & No damage & 0 \\
\hline & Inflammation, hemorrhage in less than $25 \%$ of tissue & 1 \\
\hline & (Plus) necrosis in less than $25 \%$ of tissue & 2 \\
\hline & Necrosis up to $60 \%$ & 3 \\
\hline & Necrosis more than $60 \%$ & 4 \\
\hline
\end{tabular}

\section{Statistical Analysis:}

Results were expressed as mean \pm SEM. One-way ANOVA (Analysis of Varience) was used to test for differences among the studied groups followed by LSD (Least Significant Difference) to find intergroupal significance. For differences within the same group, Student's t-test for paired data was performed. Statistical significance was performed by using SPSS (Statistical Program for Social Science), statistical Package (SPSS Inc.), version 20.0. $\mathrm{P}$ value $\leq 0.05$ was considered significant. 


\section{RESULTS}

\section{Changes in body and kidney weights} (Table 2): Non-significant differences in initial body weight (IBW) were present in the different studied groups. Final body weight (FBW) significantly increased in the sham-operated control group and I/R group compared to their respective initial values. However, the FBW significantly decreased in stressed I/R group compared to their respective initial values. I/R group showed non-significant changes in FBW and body weight percent change (\% change) as compared to sham-operated control group.

Stressed I/R group showed significantly lowered FBW and their \% change compared to I/R group and shamoperated control group.

Both kidney weight $(\mathrm{KW})$ and kidney weight/body weight (KW/BW) significantly reduced in $\mathrm{I} / \mathrm{R}$ group compared to sham-operated control group and in stressed I/R group, compared to both I/R group and sham-operated control group.

Table (2): Initial body weight (IBW, g), final body weight (FBW, g), body weight percent change (\% change), kidney weight $(\mathrm{KW}, \mathrm{mg})$ and kidney weight / body weight $(\mathrm{KW} / \mathrm{BW}, \mathrm{mg} / \mathrm{g})$ in the different studied groups

\begin{tabular}{|c|c|c|c|c|c|}
\hline \multirow{2}{*}{ Groups } & \multicolumn{3}{|c|}{ Body weight } & \multicolumn{2}{|c|}{ Kidney } \\
\hline & IBW & FBW & $\%$ Change & KW & KW/BW \\
\hline $\begin{array}{c}\text { Sham-Operated } \\
\text { Control } \\
\mathbf{P}^{*}\end{array}$ & $\begin{array}{c}296.2 \\
\pm 3.471 \\
(17)\end{array}$ & $\begin{array}{c}312.1 \\
\pm 4.224 \\
(17) \\
<0.001\end{array}$ & $\begin{array}{c}5.336 \\
\pm 0.385 \\
(17)\end{array}$ & $\begin{array}{c}2093.2 \\
+51.525 \\
(17)\end{array}$ & $\begin{array}{c}6.697 \\
\pm 0.101 \\
(17)\end{array}$ \\
\hline $\begin{array}{c}\text { Renal Ischemia/ } \\
\text { Reperfusion } \\
\mathbf{P}^{*} \\
\mathbf{P}\end{array}$ & $\begin{array}{c}295.0 \\
\pm 4.364 \\
(15) \\
\text { NS }\end{array}$ & $\begin{array}{c}309.7 \\
\pm 4.667 \\
(15) \\
<0.001 \\
\text { NS }\end{array}$ & $\begin{array}{c}4.972 \\
\pm 0.338 \\
(15) \\
\text { NS }\end{array}$ & $\begin{array}{c}1854.1 \\
\pm 39.396 \\
(15) \\
<0.001\end{array}$ & $\begin{array}{c}5.982 \\
\pm 0.067 \\
(15) \\
<0.001\end{array}$ \\
\hline $\begin{array}{c}\text { Stressed Renal } \\
\text { Ischemia/ } \\
\text { Reperfusion } \\
\mathbf{P}^{*} \\
\mathbf{P} \\
\mathbf{P}_{1}\end{array}$ & $\begin{array}{c}297.3 \\
\pm 2.004 \\
(15)\end{array}$ & $\begin{array}{c}287.3 \\
\pm 4.333 \\
(15) \\
<0.05 \\
<0.001 \\
<0.01\end{array}$ & $\begin{array}{c}-3.383 \\
\pm 1.189 \\
(15)\end{array}$ & $\begin{array}{c}1525.0 \\
\pm 61.312 \\
(15)\end{array}$ & $\begin{array}{c}5.284 \\
\pm 0.135 \\
(15)\end{array}$ \\
\hline
\end{tabular}

Results were expressed as mean \pm SEM.

In parenthesis was the number of observations.

$\mathrm{P}$ : "Significance from their initial values calculated by Student's t-test for paired data at $\mathrm{P}<0.05$.

P: Significance from sham-operated control group calculated by LSD at $\mathrm{P}<0.05$.

P1: Significance from renal ischemia/reperfusion group calculated by LSD at $\mathrm{P}<0.05$.

NS: Non significant. 
$\%$ Change: was calculated from corresponding initial values.

Changes in plasma creatinine, urea and TNF- $\alpha$ levels (Table 3): I/R group showed significant rise of plasma levels of creatinine, urea and TNF- $\alpha$ compared to sham-operated control group. Also,

Table (3): Plasma levels of creatinine $(\mathrm{mg} / \mathrm{dl})$, urea $(\mathrm{mg} / \mathrm{dl})$ and tumor necrosis factor$\alpha(\mathrm{TNF}-\alpha, \mathrm{pg} / \mathrm{ml})$ in the different studied groups.

\begin{tabular}{|c|c|c|c|}
\hline Proups & Creatinine & Urea & TNF- $\alpha$ \\
\hline Sham-Operated & 0.634 & 42.16 & 50.32 \\
Control & \pm 0.023 & \pm 2.256 & \pm 1.246 \\
& $(17)$ & $(17)$ & $(15)$ \\
\hline Renal Ischemia/ & 1.580 & 114.1 & 77.75 \\
Reperfusion & \pm 0.081 & \pm 6.549 & \pm 3.157 \\
P & $(15)$ & $(15)$ & $(15)$ \\
Stressed Renal & $<0.001$ & $<0.001$ & $<0.001$ \\
Ischemia/ & \pm 0.085 & 142.7 & 155.7 \\
Reperfusion & $(15)$ & \pm 5.475 & \pm 8.594 \\
P & $<0.001$ & $(15)$ & $(15)$ \\
P1 & $<0.001$ & $<0.001$ & $<0.001$ \\
\hline
\end{tabular}

Results were expressed as mean \pm SEM.

In parenthesis wass the number of observations.

P: Significance from sham-operated control group calculated by LSD at $\mathrm{P}<0.05$.

$\mathrm{P} 1$ : Significance from renal ischemia/reperfusion group calculated by LSD at $\mathrm{P}<0.05$.

Changes in kidney tissue MDA level, catalase activity and nitrite level (Table 4): I/R group exhibited significantly higher kidney tissue MDA and nitrite, but significantly lower kidney tissue catalase activity compared to sham-operated stressed I/R group exhibited significant elevation in plasma levels of creatinine, urea and TNF- $\alpha$ compared to both $\mathrm{I} / \mathrm{R}$ group and sham-operated control group. 
Table (4): Kidney tissue malondialdehyde (MDA, nmol/g) level, catalase activity (U/g) and nitrite level $(\mu \mathrm{mol} / \mathrm{g})$ in the different studied groups

\begin{tabular}{|c|c|c|c|}
\hline Proups & MDA & Catalase & Nitrite \\
\hline Sham-Operated & 35.42 & 17.16 & 128.9 \\
Control & \pm 4.540 & \pm 1.061 & \pm 5.770 \\
& $(16)$ & $(16)$ & $(16)$ \\
\hline Renal Ischemia/ & 621.3 & 4.724 & 661.5 \\
Reperfusion & \pm 22.24 & \pm 0.525 & \pm 18.94 \\
& $(14)$ & $(14)$ & $(14)$ \\
P & $<0.001$ & $<0.001$ & $<0.001$ \\
Stressed Renal & 788.7 & 7.057 & 903.5 \\
Ischemia/ & \pm 49.71 & \pm 0.411 & \pm 17.55 \\
Reperfusion & $(14)$ & $(14)$ & $(14)$ \\
P & $<0.001$ & $<0.001$ & $<0.001$ \\
P $_{\mathbf{1}}$ & $<0.001$ & $<0.05$ & $<0.001$ \\
\hline
\end{tabular}

Results were expressed as mean \pm SEM.

In parenthesis was the number of observations.

P: Significance from sham-operated group calculated by LSD at $\mathrm{P}<0.05$.

P1: Significance from renal ischemia/reperfusion group calculated by LSD at $\mathrm{P}<0.05$.

\section{Renal histopathological study (Figures} 1-3 and Table 1): The photomicrography of kidney tissue of sham-operated control group showed normal appearance of renal tissue as shown (Figure 1). Figure (1A) showed an intact glomerulus (g) with thin walled Bowman's capsule $(\star)$ and no tuft retraction $(\longrightarrow$ ) (Glomerular score 0 ). Figure (1B) showed that the brush border of tubular cells (t) was intact with no thickening of the basal membrane $(\star)$, no cast formation or inflammation (Tubular score 0) and no visible interstitial (i) damage as necrosis or inflammation $(\longrightarrow$ (Tubulo-Interstitial score 0). Figure (1C) showed a uniform endothelium (e) with no swelling or disruption of the endothelial cells $(\longrightarrow$ (Endothelial score 0$)$.

The photomicrography of kidney tissue of I/R group (Figure 2) demonstrated that the glomerulus (g) showed thickened Bowman's capsule $(\star)$ and glomerular tuft retraction $(\longrightarrow)$ (Glomerular score 2 - Figure 2A). In figure (2B), the tubular cells (t) showed thickened basal membrane with loss of the brush border $(\star)$ in more than $25 \%$ of the tubular cells with cast formation (c) (Tubular score 3), together with inflammation and hemorrhage $(\longrightarrow)$ which was present in less than $25 \%$ of the tissue without any evidence of necrosis (Tubulo-Interstitial score 1). Figure (3C) showed endothelial cell (e) swelling $(\longrightarrow)$ (Endothelial score 1).

The photomicrography of kidney tissue of stressed renal $\mathrm{I} / \mathrm{R}$ group was shown in figure (3). Figure (3A) the glomerulus (g) showed thickened Bowman's capsule $(\star)$ and glomerular tuft retract ion $(\longrightarrow$ ) (Glomerular score 2). Figure (3B) the tubular cells (t) showed thickened basal membrane with loss of the brush border $(\star)$ in more than $25 \%$ of the tubular cells together with cast formation (c) and necrosis $(\rightarrow$ ) in more than $60 \%$ (Tubular score 4$)$, as well as hemorrhage $(\longrightarrow$ ) within the interstitial (i) compartment with necrosis $(\rightarrow$ ) in up to $60 \%$ of the cells (Tubulo-Interstitial score 3). Figure (3C) 
NOHA S. SOBHY et al.

showed endothelial cell (e) disruption $\quad(\rightarrow)$ (Endothelial score 2).
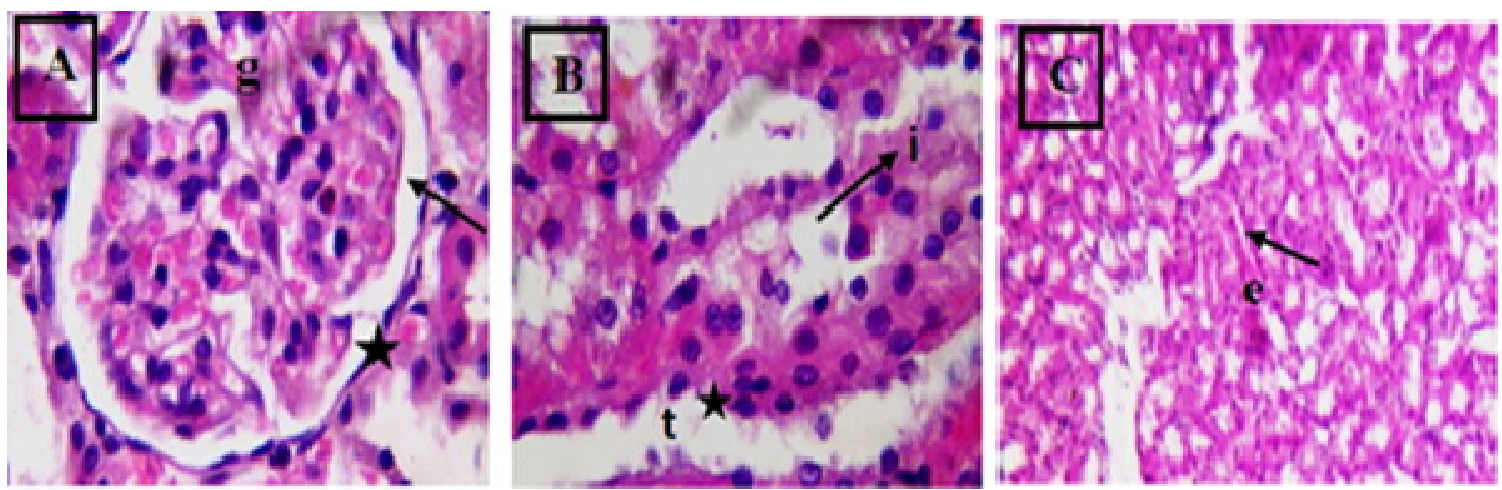

Figure (1): Photomicrograph of kidney tissue sections of sham-operated control group
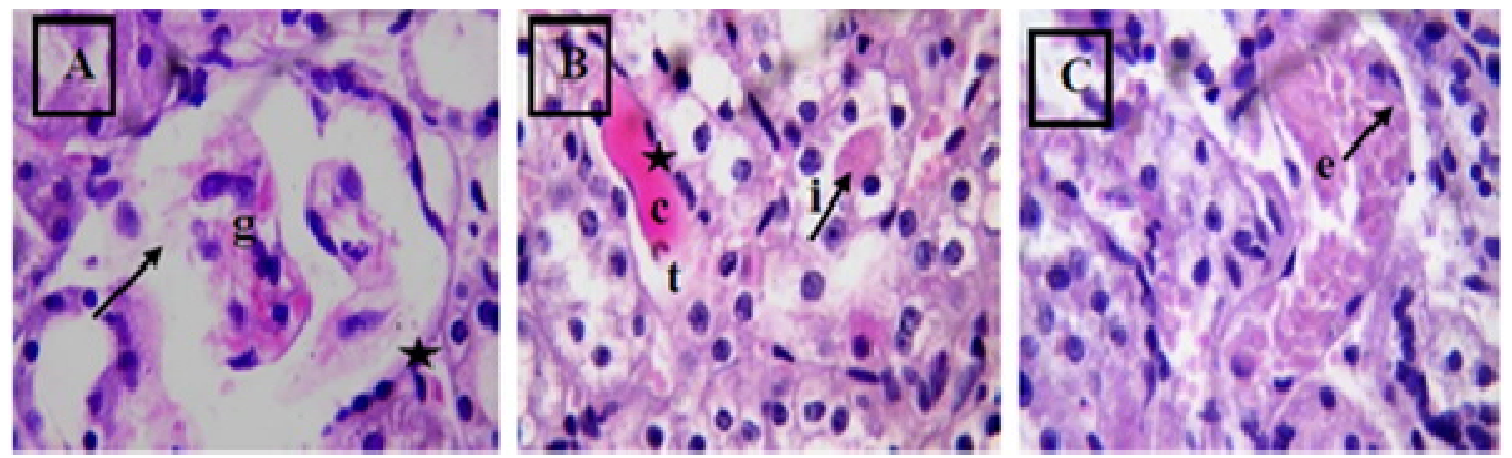

Figure (2): Photomicrograph of kidney tissue sections of I/R group
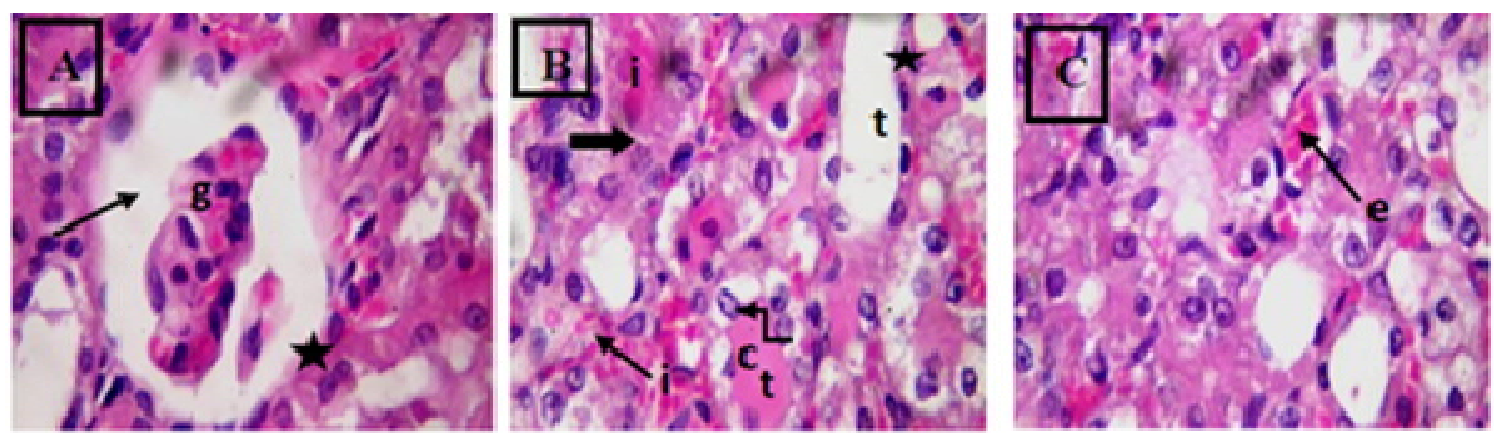

Figure (3): Photomicrograph of kidney tissue sections of stressed I/R group 


\section{DISCUSSION}

The present study was designed to evaluate renal changes in an experimental rat model of renal $\mathrm{I} / \mathrm{R}$ injury subjected to chronic immobilization stress, which is novel in demonstrating the combined effects of immobilization stress and renal $\mathrm{I} / \mathrm{R}$ on renal function and structure.

In this study, the high plasma creatinine and urea levels observed in I/R group were consistent with several previous studies (Hagiwara et al., 2011; Kanani et al., 2016 and Najafi et al., 2017), and indicated detrimental glomerular filtration, and thus, impairment of renal function. The glomerular Bowman's capsular basement membrane thickening demonstrated in the present histopathological renal study could, also, point to the disturbed glomerular filtration (Banaei et al., 2016).

Meanwhile, renal tubular function could have been disturbed as a result of the present renal tubular injury induced by the ischemic insult, since tubular cells displayed thickening of basement membrane together with loss of brush borders associated with cast formation, which indicated cell death and sloughing that lead to tubular obstruction. In agreement, (Khalid et al., 2016) reported that, in I/R injury, hypoxia results in loss of brush border membrane leading to loss of polarity and integrity of tight junctions. Also, cast formation occurred secondary to cell death and sloughing. Cast formation and other debris led to tubular obstruction. These changes, along with tubular necrosis, signified extensive tubular damage. In addition, tubular injury is a characteristic feature of renal $I / R$ injury, since the tubules are most prone to ischemic damage, and therefore, acute tubular necrosis is a hallmark of kidney injury (Patschan et al., 2012).

In the present study, the kidney tissue of renal I/R group displayed significant elevation in MDA; an important parameter of oxidative stress and a good pointer of lipid peroxidation associated with significant reduction in catalase activity, an antioxidant enzyme, findings that imply that the kidneys exposed to ischemic reperfusion insult are rich in ROS and are defective in the endogenous enzymatic antioxidant defense mechanisms, and thereby are suffering from an oxidative stress state (Hong et al., 2017). Such imbalance of renal tissue oxidants and antioxidants mechanism could provide explanation for the observed disturbed kidney function (Sureshbabu et al., 2015).

Hypoxia, which results from ischemia and subsequent reperfusion, is characterized by increased production of ROS and decreased efficacy of the antioxidant defenses (Rabie et al., 2012). Oxidative stress was reported to be considered as the key step in the initiation and development of renal $\mathrm{I} / \mathrm{R}$ injury (Rovcanin et al., 2016). ROS are initially triggered by dysfunction of the mitochondrial respiratory chain in the ischemic phase and magnified in the reperfusion phase via peroxidation of membrane lipids and oxidative damage of proteins and DNA causing apoptosis and cell death (Kalogeris et al., 2014 and Hong et al., 2017). Also, ROS increases plasma membrane permeability and modulate both enzyme and membrane pump activity (Miloradović et al., 2014) The effect of the large amount of free 
ROS generated by reperfusion injury could not be "buffered" by endothelial cells exposed to ischemia (Radovic et al., 2006).

Also, the renal I/R group showed high plasma level of TNF- $\alpha$, which suggested increased synthesis and release of proinflammatory cytokines, thus, referring to the presence of an inflammatory process. Evidence of inflammation in renal tubular cells and within the interstitium are demonstrated by the renal histopathological examination. The enhanced TNF- $\alpha$ production may result from increased generation of ROS in renal I/R injury (Gabr et al., 2011). Oxygen free radicals stimulate monocytes to produce TNF- $\alpha$ (Gezginci-Oktayoglu et al., 2016). Park et al.( 2017) reported that the pathogenesis of renal I/R injury involves the release of proinflammatory cytokines such as TNF- $\alpha$, transforming growth factor- $\beta$ and nuclear factor- $B$, and ROS .

In addition, another mechanism proposed to be involved in the impaired kidney function observed in renal $I / R$ group could be high nitric oxide (NO) level in renal tissue, since the kidney content of nitrite, the stable NO metabolite was found to be elevated. In agreement to this explanation, (Hussein et al., 2014) showed that NO plays an important role in mediating cell damage during I/R injury. This current high renal tissue nitrite is suggested to be attributed to an increase in enzymes synthesizing NO. This speculation is in accordance to the study by (Masoud et al., 2012) reporting that high NO levels, produced by inducible nitric oxide synthase (iNOS) enzyme, were found to be implicated in the renal dysfunction and injury with renal I/R. In addition, (Malek and Nematbakhsh, 2015) showed that NO (one of the inflammatory mediators) is produced in renal $\mathrm{I} / \mathrm{R}$ via the activity of iNOS. Several studies have shown an increased iNOS activity in renal I/R (Kezic et al., 2013; Ghasemi et al., 2015 and Kanani et al., 2016). Also, renal I/R was found to cause the expression of iNOS mRNA and protein within the kidney (Betz et al., 2012).

The present renal histopathology in the $\mathrm{I} / \mathrm{R}$ group showed endothelial cell swelling which in turn could disturb endothelial NOS (eNOS) which inhibited formation of endothelial form of $\mathrm{NO}$, and reflected that the elevated $\mathrm{NO}$ in the present study was most properly produced by iNOS.

Moreover, the increased renal tissue nitrite in renal I/R group could, also, be further explained by the significant increase of the proinflammatory marker, TNF- $\alpha$ (Aragno et al., 2003). The oxidative stress in ischemia has been shown to activate a transcription factor, nuclear factor- $\kappa \mathrm{B}$, which is an inducible transcription factor that is sequestered in the cytoplasm in inactive form and when activated, it translocates from cytoplasm to nucleus, where it binds to $\kappa \mathrm{B}$ DNA promoter sites and transactivates a number of proinflammatory genes, including nitric oxide synthase (NOS), intercellular adhesion molecule, vascular cell adhesion molecule, endothelial selectin and TNF- $\alpha$ (Gabr et al., 2011).

Many of the ROS activate the signaling mechanisms that culminate in TNF- $\alpha$ production (Farag et al., 2016), TNF- $\alpha$, dramatically induces iNOS mRNA in 
epithelial tubular cells, and this is associated with increased NO production (Aragno et al., 2003).

The study of the effect of stress in renal $I / R$ is a novel approach. In this study, combination of chronic immobilization stress followed by renal $\mathrm{I} / \mathrm{R}$ resulted in aggravation of the picture seen in I/R group alone. the oxidative, mechanism and The endocrine and nervous systems could explain the findings observed in the stressed group (Samarghandian et al., 2017).

The significant elevation in creatinine and urea shown in the stressed group subjected to renal $\mathrm{I} / \mathrm{R}$ in comparison to non-stressed renal I/R group indicated that stressed rats suffered more deterioration in their kidney functions. Thus, stressed rat kidneys were exposed to dual insults; that of stress added to ischemia which aggravated the renal impairment. Also, stress potentiated the renal histopathological derrangement imposed by renal $\mathrm{I} / \mathrm{R}$ as indicated by the greater degree of glomerular injury as well as acute tubular necrosis; tubular and tubulointerstitial necrosis exceeding more than $60 \%$ of the cells together with disruption of endothelial cells. Thus, the greater impairment of glomerular and tubular function by stress is in harmony with the renal structural damage

The further higher level of renal tissue MDA exhibited by rats subjected to chronic immobilization stress, could be implicated in the additional renal dysfunction (higher plasma creatinine and urea) induced by stress. Stress is a state that threatens the homeostasis and balance of a living organism (Chrousos, 2009) and immobilization stress which induces both psychological and physical stress (Zhu et al., 2014).It was reported to be associated with oxidative damage (Al-Rejaie et al., 2012). Stress was reported to shift the oxidants and antioxidant balance, by stimulating numerous pathways elevating the production of oxidants. Thus, stress may be an additional factor to the oxidant burden associated with normal aerobic metabolism, with subsequent damage to lipid resulting in many diseases (Nayanatara et al., 2012). The authors added that the generation of ROS is a primary event under a variety of stress conditions and the consequence of ROS formation depends on the intensity of the stress.

As a stress response to immobilization, more ROS are produced that causes lipid peroxidation, especially in membranes of tissues, thereby causing more detrimental factors of tissue injury (Abdulrauf et al., 2018). Meanwhile, renal tissue catalase increased in renal IR group following stress. It seems that upon exposure to stress, the antioxidant defence mechanisms represented in the present study by catalase, were activated and the observed high catalase in stressed $I / R$ group was an attempt to face and counteract the overproduced oxidants. However, unfortunately, it failed to achieve this function as renal MDA remained elevated by immobilization stress, and even exceeded its levels in the non-stressed renal I/R group .

The increased renal tissue catalase activity in the present work was in line with the study of Şahin and Gümüşlü (2007) which reported that hydrogen peroxide (H2O2), one of the ROS produced more during chronic 
immobilization stress, may be detoxified mainly by catalase in the kidney tissue. Thus, catalase acts as an antioxidant enzyme at high concentrations of $\mathrm{H} 2 \mathrm{O} 2$.

On the contrary, Samarghandian et al. (2016) found significant reduction in renal tissue catalase activity in a model of rats immobilized for 6 hours per day for 21 consecutive days, suggesting that the overproduced ROS inactivates the catalase antioxidant activity. This discrepancy from the present result could be explained by difference in the experimental model used.

Chronic immobilization stress has been found to induce many damaging processes such as mitochondrial dysfunction, disruption of energy pathways and induction of signaling events in apoptotic cell death (Zafir \& Banu, 2009 and Grizzell et al., 2014). This could provide further explanation to the present stressmediated aggravation of renal tubular and tubulointerstitial necrosis.

In the current study, the observed significant elevation in plasma TNF- $\alpha$ in stressed renal I/R group agreed with the study of Himmerich et al. (2013) who reported that stress can induce secretion of proinflammatory cytokines such as TNF$\alpha$. This high plasma TNF- $\alpha$ found in the current study rats upon exposure to chronic immobilization and I/R, reaching double the value of the unstressed I/R group, could be attributed to stress induced activation of the sympathetic nervous system-adrenal medulla and the hypothalamic-pituitary-adrenal (HPA) axis that stimulates secretion of catecholamines (noradrenaline and adrenaline) and glucocorticoid respectively. These mediators are capable of modulating immune cells and further modulating cytokine production (Webster Marketon \& Glaser, 2008 and Tian et al., 2014).

Additionally, in the present study, stressed renal $\mathrm{I} / \mathrm{R}$ group developed significant elevation in renal tissue nitrite compared to renal I/R that was associated with endothelial cell disruption by histological examination and significantly increased endothelial injury score. From these results, endothelial dysfunction could be speculated and, thus, the high renal tissue nitrite could be of inducible origin (produced by iNOS and not eNOS). These speculations could be supported by the study of Chung et al. (2010) who found that chronic immobilization stress led to endothelial dysfunction. Also, oxidative stress causes endothelial dysfunction by impairing endotheliumdependent relaxation and by inducing intracellular calcium overload and DNA fragmentation (Higashi et al., 2009).

The exaggerated increase in plasma TNF- $\alpha$ and renal tissue nitrite in the stressed renal I/R group concomitant with the exaggerated elevation in plasma creatinine and urea level reflect the possible indulgment of both TNF- $\alpha$ and $\mathrm{NO}$ in the aggravated reduction in renal function associating chronic immobilization stress.

Moreover, in this study, rats of the stressed renal $\mathrm{I} / \mathrm{R}$ group exhibited significant decrease in FBW, as well as in their absolute and relative kidney weights compared to $\mathrm{I} / \mathrm{R}$ and sham-operated control groups. Similarly, a study by $d e$ Souza et al. (2011) found a significant reduction in FBW in rats immobilized for 2 hours daily for 5 weeks compared to 
sham-operated control group. Corticotrophin-releasing hormone which is reported to influence feeding behavior and mediate behavioral and physiological response to stress, is assumed to provide explanation for such weight changes. In addition, corticotrophin-releasing hormone induces anorexia during stress. Such effect may be due to either activation of serotonin pathways or inhibition of neuropeptide Y release, a potent stimulator of food intake (Nayanatara et al., 2012).

\section{CONCLUSION}

Renal I/R impaired functional and structural integrity of the kidney. Chronic immobilization stress hypersensitized the kidney to renal I/R injury that exaggerated the deleterious effect of renal $I / R$. Oxidative stress, activated inflammatory response and NO enhancement participated in the stress-aggravating effect of renal I/R.

\section{REFERENCES}

1. Abdulrauf, R.A., Dawud, F.A., Emmanuel, N.S., Muhammad, H.D., Dange, A.S., David, B.A., Ogweje, A.E., Alexander, A.U. and Yahuza, M. (2018): Lipid Peroxidation and Some Antioxidant Enzymes Evaluation in Apple Cider Vinegar (ACV) Treated Male and Female Wistar Rats. Exposed to Chronic Restraint Stress. Advances in Enzyme Research, 6: 21-28.

2. Aebi, H. (1984): Catalase in vitro. Methods on enzymology, 105: 121-126.

3. Al-Rejaie, S.S., Abuohashish, H.M., Moahmmed, M.A., Aleisa, A.M., Alroujayee, A.S. and Alkhamees, O.A. (2012): Immobilization stress-induced oxidative damage and its amelioration with green and black teas. African Journal of Pharmacy and Pharmacology, 6(8): 538-545.

4. Aragno, M., Cutrin, J.C., Mastrocola, R., Perrelli, M-G., Restivo, F., Poli, G., Danni,
O. and Boccuzzi, G. (2003): Oxidative stress and kidney dysfunction due to ischemia/reperfusion in rat: attenuation by dehydroepiandrosterone. Kidney International, 64: 836-843.

5. Banaei, S., Ahmadiasl, N. and Alihemmati, A. (2016): Comparison of the Protective Effects of Erythropoietin and Melatonin on Renal Ischemia-Reperfusion Injury. Trauma Monthly, 21(3): e23005.

6. Bartels, H., B?hmer, M. and Heierli, C. (1972): Serum creatinine determination without protein precipitation. Clinica Chimica Acta; International Journal of Clinical Chemistry , 37: 193-197.

7. Betz, B., Schneider, R., Kress, T., Schick, M.A., Wanner, C. and Christoph Sauvant, C. (2012): "Rosiglitazone Affects Nitric Oxide Synthases and Improves Renal Outcome in a Rat Model of Severe Ischemia/Reperfusion Injury," PPAR Research, 2012(219319): 1-12.

8. Bitgul, G., Tekmen, I., Keles, D. and Oktay, G. (2013): Protective effects of resveratrol against chronic immobilization stress on testis. ISRN Urology, 278720.

9. Bonventre, J.V. and Yang, L. (2011): Cellular pathophysiology of ischemic acute kidney injury. Journal of Clinical Investigation, 121(11): 4210-4221.

10. Buynitsky, T. and Mostofsky, D.I. (2009): Restraint stress in biobehavioral research: recent developments. Neuroscience and Biobehavioral Reviews, 33(7): 1089-1098.

11. Chen, G. Y. and Nu?ez, G. (2010): Sterile inflammation: sensing and reacting to damage. Nature reviews. Immunology, 10(12): 826-837.

12. Chrousos, G.P. (2009): Stress and disorders of the stress system. Natural Reviews. Endocrinology, 5(7): 374-381.

13. Chung, I.M., Kim, Y.M., Yoo, M.H., Shin, M.K., Kim, C.K. and Suh, S.H. (2010): Immobilization stress induces endothelial dysfunction by oxidative stress via the activation of the angiotensin II/its type I receptor pathway. Atherosclerosis, 213(1): 109114. 
14. Cook, H.C. (1974): Manual of histological demonstration techniques. Pbl. Butter worth and Co., London: PP.195-213.

15. de Souza, D.B., Silva, D., Silva, C. M.C., Sampaio, F.J.B., Costa, W.S. and Cortez, C.M. (2011): Effects of Immobilization Stress on Kidneys of Wistar Male Rats: A Morphometrical and Stereological Analysis. Kidney and Blood Pressure Research, 34(6): 424-429.

16. Farag, M.M., Khalifa, A.A., Elhadidy, W.F. and Rashad, R.M. (2016): Hepatorenal protection in renal ischemia/reperfusion by celecoxib and pentoxifylline. The Journal of surgical research, 204(1): 183-189.

17. Fawcett, J.K. and Scott, J.E. (1960): A rapid and precise method for the determination of urea. Journal of Clinical Pathology, 13(2): 156159.

18. Gabr, M.M., Hussein, A.M., Sherif, I.O., Ali, S.I. and Mohamed, H.E. (2011): Renal ischemia/reperfusion injury in type II DM: possible role of proinflammatory cytokines, apoptosis, and nitric oxide. Journal of Physiology and Pathophysiology, 2(1): 6-17.

19. Gardner, D.S., De Brot, S., Dunford, L.J., Grau-Roma, L., Welham, S.J., Fallman, R., O'Sullivan, S.E., Oh, W. and Devonald, M.A. (2016): Remote effects of acute kidney injury in a porcine model. American Journal of Physiology, Renal Physiology, 310(4): 259271.

20. Gezginci-Oktayoglu, S., Orhan, N. and Bolkent, S. (2016): Prostaglandin-E1 has a protective effect on renal ischemia/reperfusioninduced oxidative stress and inflammation mediated gastric damage in rats. Intenational Immunopharmacology, 36: 142-150.

21. Ghasemi, M., Nematbakhsh, M., Daneshmand, F., Moeini, M. and Talebi, A. (2015): Role of nitric oxide in kidney and liver (as distance organ) function in bilateral renal ischemia-reperfusion: Effect of L-Arginine and NG-nitro-L-Arginine methyl ester. Advanced biomedical research, 4: 233.

22. Gholampour, H., Moezi, L. and Shafaroodi, H. (2017): Aripiprazole prevents renal ischemia/reperfusion injury in rats, probably through nitric oxide involvement. European Journal of Pharmacology, 813: 17-23.

23. Granger, D. N. and Kvietys, P.R. (2015): Reperfusion injury and reactive oxygen species: The evolution of a concept. Redox biology, 6: 524-51.

24. Grizzell, J.A., Iarkov, A., Holmes, R., Mori, T. and Echeverria, V. (2014): Cotinine reduces depressive-like behavior, working memory deficits, and synaptic loss associated with chronic stress in mice. Behavioural Brain Research, 268: 55-65.

25. Hagiwara, S., Koga, H., Iwasaka, H., Kudo, K., Hasegawa, A., Kusaka, J., Yokoi, I. and Noguchi, T. (2011): ETS-GS, a new antioxidant, ameliorates renal ischemiareperfusion injury in a rodent model. Journal of Surgical Research, 171(1): 226-233.

26. Higashi, Y., Noma, K., Yoshizumi, M. and Kihara Y (2009): Endothelial function and oxidative stress in cardiovascular diseases. Circulation Journal, 73(3): 411-418.

27. Himmerich, H., Fischer, J., Bauer, K., Kirkby, K.C., Sack, U. and Krügel, U. (2013): Stress-induced cytokine changes in rats. European Cytokine Network, 24(2): 97-103.

28. Hong, X., Zhao, X., Wang, G., Zhang, Z., Pei, H. and Liu, Z. (2017): Luteolin treatment protects against renal ischemia-reperfusion injury in rats. Mediators of inflammation, 2017(9783893): 1-10.

29. Hussein, A.M., Khaled, H.K., Seisa, M.O., Baiomy, A., Mohamed, M.A., Eltantawy, D., Mahmoud, A.A., Sheashaa, H.A. and Sobh, M.A. (2014): Possible role of nitric oxide in hepatic injury secondary to renal ischemiareperfusion (I/R) injury. General Physiology and Biophysics, 33(2): 205-213.

30. Kalogeris, T., Bao, Y. and Korthuis, R.J. (2014): Mitochondrial reactive oxygen species: A double edged sword in ischemia/reperfusion vs preconditioning. Redox Biology, 2: 702-714.

31. Kanani, F., Fazelnia, F., Mojarradfard, M., Nematbakhsh, M., Moslemi, F., EshraghiJazi, F. and Talebi, A. (2016): Role of Smethylisothiourea (SMT) in renal ischemia/reperfusion injury in rats. Journal of Renal Injury Prevention, 5(1): 29-33. 
32. Kezic, A., Thaiss, F., Becker, J.U., Tsui, T.Y. and Bajcetic, M. (2013): Effects of everolimus on oxidative stress in kidney model of ischemia/reperfusion injury. American Journal of Nephrology, 37(4): 291-301.

33. Khalid, U., Pino-Chavez, G., Nesargikar, P., Jenkins, R.H., Bowen, T., Fraser, D.J. and Chavez, R. (2016): Kidney ischaemia reperfusion injury in the rat: the EGTI scoring system as a valid and reliable tool for histological assessment. Journal of Histology and Histopathology, 3(1): 1-7.

34. Kosieradzki, M. and Rowiński, W. (2008): Ischemia/reperfusion injury in kidney transplantation: mechanisms and prevention. Transplantation Proceedings, 40(10): 32793288.

35. Li, C., Guo, Z., Zhao, R., Sun, W. and Xie, M. (2017): Proteomic Analysis of Liver Proteins in a Rat Model of Chronic Restraint Stress-Induced Depression. BioMed Research International, 2017(7508316):1- 14.

36. Malek, M. and Nematbakhsh, M. (2015): Renal ischemia/reperfusion injury; from pathophysiology to treatment. Journal of Renal Injury Prevention, 4(2): 20-27.

37. Masoud, M.S., Anwar, S.S., Afzal, M.Z., Mehmood, A., Khan, S.N. and Riazuddin, S. (2012): Pre-conditioned mesenchymal stem cells ameliorate renal ischemic injury in rats by augmented survival and engraftment. Journal of Translational Medicine, 10: 243.

38. Miloradović, Z., Ivanov, M., MihailovićStanojević, N., Grujić Milanović, J., Jovović, Đ., Vajić, U.J. and Marković-Lipkovski, J. (2014): Acute superoxide radical scavenging reduces blood pressure but does not influence kidney function in hypertensive rats with postischemic kidney injury. BioMed research international, 2014(512619) 1-8.

39. Mohamed, F.A., Ahmed, A.A., Ahmed, M.A. and Lasheen, N.N. (2007): SeleniumInduced modulation of intestinal motility changes in stressed rats. Ain Shams Medical Journal, 58: 4-6.

40. Montgomery, H.A.C. and Dymock, J. (1961): The management of ingrowing toenails. BMJ., 344: 37-40.
41. Munshi, R., Hsu, C. and Himmelfarb, J. (2011): Advances in understanding ischemic acute kidney injury. BMC Medicine, 9: 11.

42. Najafi, H., Mohamadi Yarijani, Z., Changizi-Ashtiyani, S., Mansouri, K., Modarresi, M., Madani, S. H. and Bastani, B. (2017): Protective effect of Malva sylvestris L. extract in ischemia-reperfusion induced acute kidney and remote liver injury. PLoS ONE, 12(11): e0188270.

43. Nayanatara, A.K., Tripathi, Y., Nagaraja, H.S., Jeganathan, P.S., Ramaswamy, C., Ganaraja, B., Pai, S.R. and Kamath, A. (2012): Effect of Chronic Immobilization Stress on some selected Physiological, Biochemical and Lipid Parameters in Wistar Albino Rats. Research Journal of Pharmaceutical, Biological and Chemical Sciences, 3(1): 34-42.

44. Ohkawa, H., Ohishi, N. and Yagi, K. (1979): Assay of lipid peroxides in animal tissue by thiobarbituric acid reaction. Analytical Biochemistry, 95(2): 351-358.

45. Park, J.S., Choi, H.I., Bae, E.H., Ma, S.K. and Kim, S.W. (2017): Small heterodimer partner attenuates hydrogen peroxide-induced expression of cyclooxygenase- 2 and inducible nitric oxide synthase by suppression of activator protein-1 and nuclear factor- $\kappa \mathrm{B}$ in renal proximal tubule epithelial cells. International Journal of Molecular Medicine, 39(3): 701-710.

46. Patschan, D., Patschan, S. and Müller, G.A. (2012): Inflammation and microvasculopathy in renal ischemia reperfusion injury. Journal of Transplantation, 2012(764154): 1-7.

47. Rabie, M.A., Zaki, H.F., Bahgat, A.K. and Abd El-Latif, H.A. (2012): Angiotensin antagonists and renal ischemia/reperfusion: Possible modulation by L-carnitine. Bulletin of faculty of pharmacy, Cairo university, 50: 7-16.

48. Radovic, M., Miloradovic, Z., Popovic, T., Mihailovic-Stanojevic, N., Jovovic, D., Tomovic, M., Colak, E., Simic-Ogrizovic, S. and Djukanovic, L. (2006): Allopurinol and enalapril failed to conserve urinary NOx and sodium in ischemic acute renal failure in spontaneously hypertensive rats. The American Journal of Nephrology, 26(4): 388-399. 
49. Rovcanin, B., Medic, B., Kocic, G., Cebovic, T., Ristic, M. and Prostran, M. (2016): Molecular Dissection of Renal IschemiaReperfusion: Oxidative Stress and Cellular Events. Current Medicinal Chemistry, 23(19): 1965-1980.

50. Şahin, E. and Gümüşlü, S. (2007): Immobilization stress in rat tissues: Alterations in protein oxidation, lipid peroxidation and antioxidant defense system. Comparative Biochemistry and Physiolology Part C: Toxicology and Pharmacology, 144(4): 342347.

51. Samarghandian, S., Farkhondeh, T., Samini, F. and Borji, A. (2016): Protective Effects of Carvacrol against Oxidative Stress Induced by Chronic Stress in Rat's Brain, Liver, and Kidney. Biochemistry Research International, 2016(2645237): 1-7.

52. Samarghandian, S., Nezhad, M.A., Borji, A., Samini, M. and Farkhondeh, T. (2017): Protective effects of carnosol against oxidative stress induced brain damage by chronic stress in rats. BMC Complementary and Alternative Medicine, 17(1): 249.

53. Satoh, K. (1978): Serum lipid peroxide in cerebrovascular disorders determined by a new colorimetric method. Clinica Chimica Acta, International Journal of Clinical Chemistry, 90(1): 37-43.
54. Sureshbabu, A., Ryter, S. W. and Choi, M.E. (2015): Oxidative stress and autophagy: crucial modulators of kidney injury. Redox biology, 4: 208-214.

55. Tian, R., Hou, G., Li, D., and Yuan, T.F. (2014): A possible change process of inflammatory cytokines in the prolonged chronic stress and its ultimate implications for health. The Scientific World Journal, 2014(780616): 1-8.

56. Webster Marketon, J.I. and Glaser, R. (2008): Stress hormones and immune function. Cellular Immunology, 252(1-2): 16-26.

57.Yeboah, M.M., Xue, X., Duan, B., Ochani, M., Tracey, K.J., Susin, M. and Metz, C.N. (2008): Cholinergic agonist attenuate renal ischemia- reperfusion injury in rats. Kidney International, 74(1): 62-69.

58. Zafir, A. and Banu, N. (2009): Induction of oxidative stress by restraint stress and corticosterone treatments in rats. Indian Journal of Biochemistry and Biophysics, 46(1):53-58.

59. Zhu, Q., Gu, L., Wang, Y., Jia, L., Zhao, Z., Peng, S. and Lei, L. (2014): The Role of Alpha-1 and Alpha-2 Adrenoceptors in Restraint Stress-Induced Liver Injury in Mice. PLoS ONE, 9(3): e92125. 


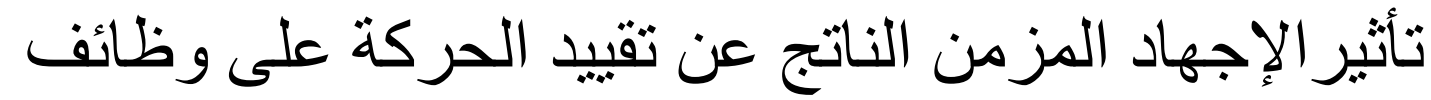

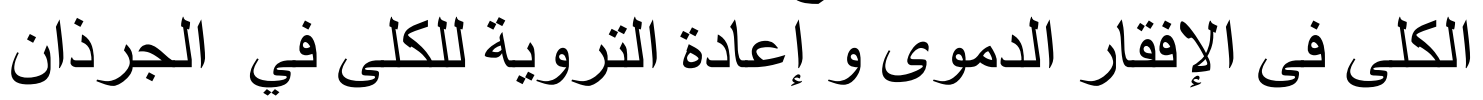
نهى سيا صبحى، منى أحمد أحمد، نهى نوح لاثين، محمد حسن السيد، ولاء باهر قسم الفسيولوجيا الطبية، و قسم الهيستولوجى و بيولوجيا الخلية، كلية الطب، جامعة عين شس

خلفية البحث : تعد الإصابة بالإفقار الدموى و إعادة التروية للكلي واحدة من أهم و أكثر الأسباب شيو عا

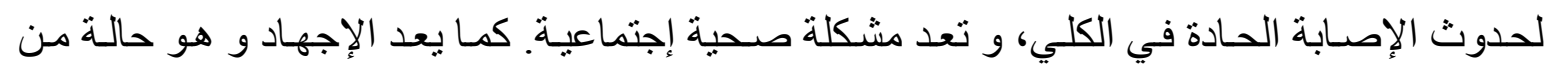
الإضطر اب في التوازن الطبيعي سببا فى تطور العديد من الأمر اض الفسيولودية.

الهاف من البحث: يهدف البحث إلى دراسة التغير ات في وظائف ونسيج الكلى التي تتنج عن إصـابة

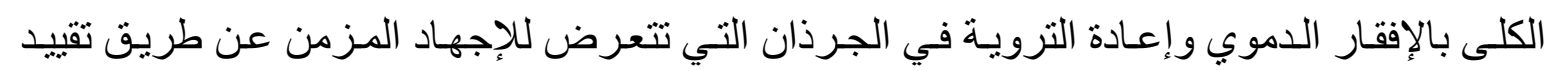

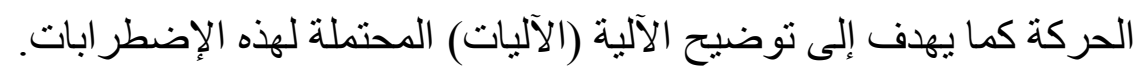
مواد وطرق البحث: أجريت هذه الدراسـة على Vـ مـن الجرذان الذكور البـالغين، و قد تم تقسيم

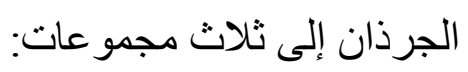

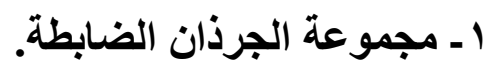

Y ـ مجموعة الجرذان المصابة بالإققار الدموي وإعادة التروية للكلى: خضعت الجرذان فى هذه

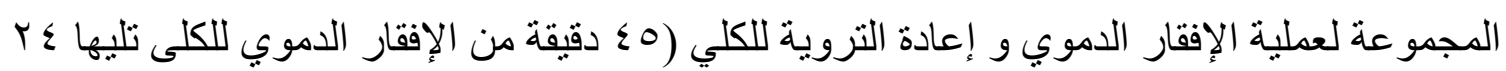
ساعة من إعادة التروية).

rـ ـ مجموعة الجرذان المعرضة للإجهاد و المصابة بالإققار الاموي وإعادة التروية للكلى: تعرضت

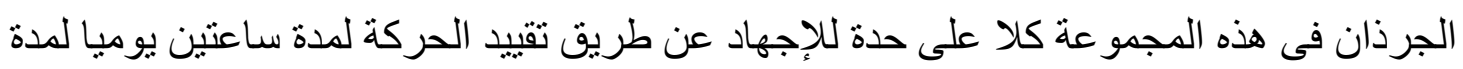
أربعة أسابيع، و بعدها تعرضت الجرذان لعملية الإفقار الدموي و إعادة التروية للكلي.

و قد تعرضت الجرذان في جميع المجموعات للاراسات الآتية:

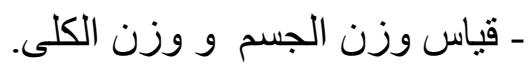
ـ قياس مستوى الكرياتينين و اليورياو مؤشر الإلتهاب (Tumor necrosis factor-

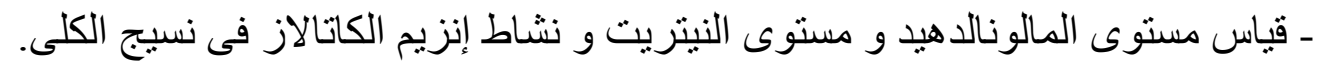
ـ عمل فحص ميكروسكوبى لنسيج الكلى. 
النتائج: أظهرت الجرذان المعرضة للإجهاد و المصابة بالإفقار الدموي وإعادة التروية للكلى إنخفاضًا

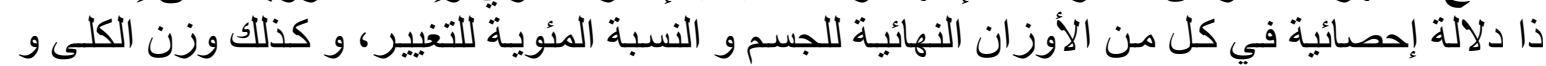

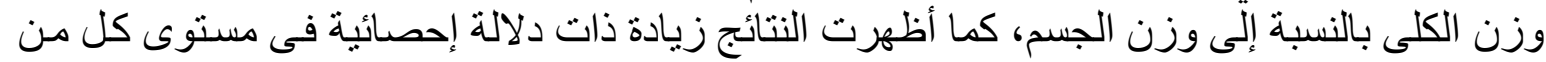
الكرياتينين و اليوريا و و مؤشر الإلتهاب (Tumor necrosis factor-

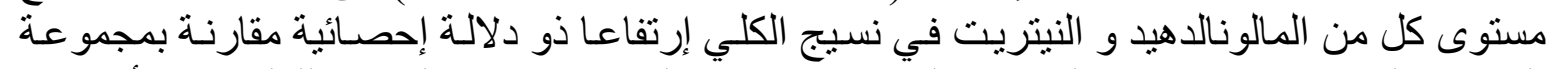

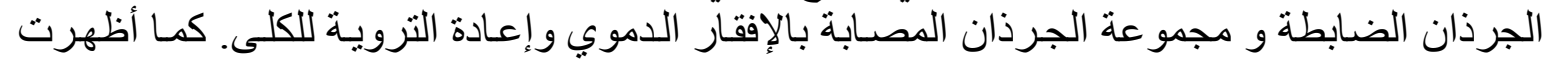

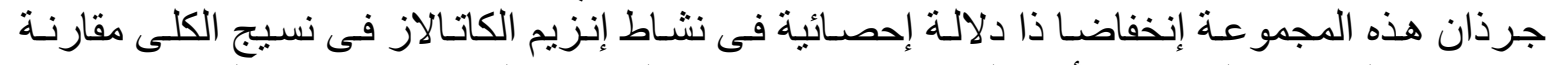

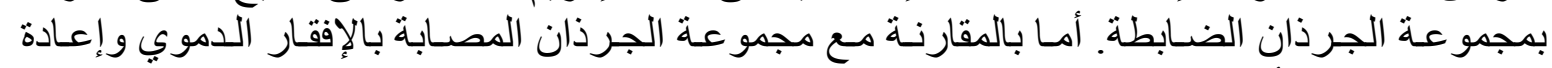
التروية للكلى فقد أظهر نشاط إنزيم الكاتالاز زيادة ذات دلانة إلة إحصائية.

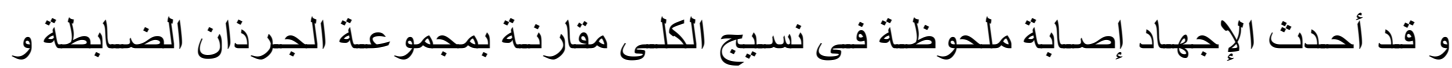

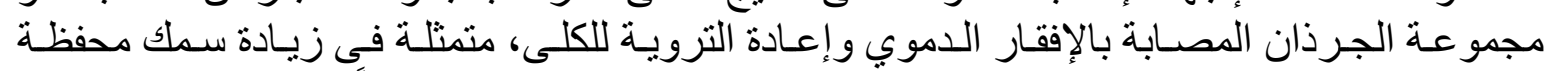

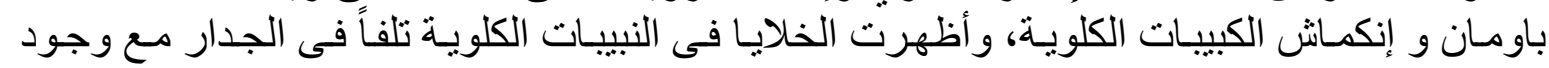

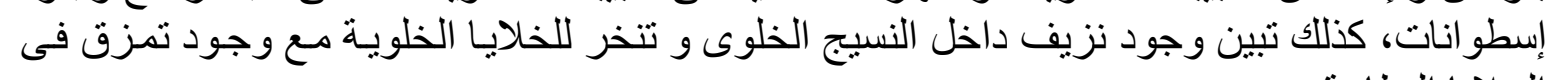

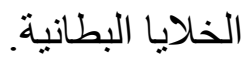

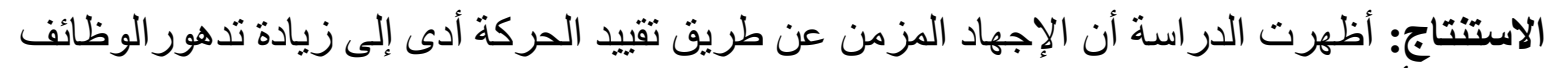

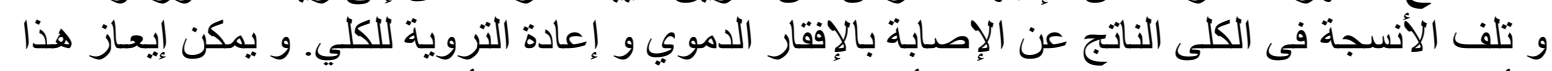
التأثثر الضار للإجهاد إلى زيادة عوامل الأكسدة و مؤشرات الإلى الإلتهاب و أكسيد النيتريك. 